\title{
Effects of some insecticides on the division of a Spodoptera littoralis cell line and on the replication of $S l$ Baculovirus (NPV)
}

\author{
O. Khamiss, X. Lery, M. H. Belal, ${ }^{1}$ H. A. Badawy, ${ }^{1}$ J. Gianotti and S. M. Abol-Ela \\ Entomovirology Laboratory, Faculty of Agriculture/ORSTOM, Giza, Egypt \\ ${ }^{1}$ Department of Economic Entomology and Pesticides, Faculty of Agriculture, Cairo University, Giza, Egypt
}

(Received 28 October 1996; Accepted 7 November 1997)

\begin{abstract}
The impact of several insecticides has been studied on a Spodoptera littoralis cell line and their effects on the replication of $S$. littoralis nucleopolyhedrovirus ( $S l$ NPV). Four chemical insecticides, Chloropyrifos, Fenitrothion, Cypermethrin and Carbaryl which belong to three different groups of pesticide, organophosphorus, pyrethroid, and carbamate, respectively, were used. The results demonstrate an increase of more than $25 \%$ in the multiplication of $S l$ cells when treated with Chloropyrifos dilutions compared with untreated cells. The most destructive pesticide was Cypermethrin, which caused $84 \%$ inhibition of cell development $(0.4 \times$ $10^{6} \mathrm{cell} / \mathrm{ml}$ ) at a concentration of $10^{-3} \mu \mathrm{g} / \mathrm{ml}$ in preliminary tests. In the presence of both $S l \mathrm{NPV}$ and sublethal doses of these insecticides, the $\mathrm{TCID}_{50}$ values revealed that the Cypermethrin $\left(10^{-8} \mu \mathrm{g} / \mathrm{ml}\right)$ was the most toxic $\left(\mathrm{ID}_{50}\right.$ was $\left.6.48 \times 10^{5} / \mathrm{ml}\right)$ whereas Chloropyrifos was the least toxic $\left(\mathrm{ID}_{50} 9.29 \times 10^{12} / \mathrm{ml}\right)$ at a concentration of $0.731 \mu \mathrm{g} / \mathrm{ml}$. The PFU values confirm the results that the same concentration of Chloropyrifos $(0.731$ $\mu \mathrm{g} / \mathrm{ml}$ ) was the least toxic (PFU $\left.6.41 \times 10^{13} / \mathrm{ml}\right)$ and Cypermethrin was the most toxic $\left(4.47 \times 10^{6} / \mathrm{ml}\right.$ PFU) for the other concentrations as well as the different insecticides the PFU values ranged between $2.8 \times 10^{8}$ for Chloropyrifos at a concentration of $10^{-3} \mu \mathrm{g} / \mathrm{ml}$ and $9.76 \times 10^{12}$ for Carbaryl at $10^{-5} \mu \mathrm{g} / \mathrm{ml}$. A comparison with the results obtained using $S l$ NPV without chemicals (the PFU $3.5 \times 10^{9} / \mathrm{ml}$ ) indicates an increase in the production of virus and titer, and a synergistic effect of the chemicals. These results confirm the effect of these insecticides in vivo. As the Cypermethrin may have a potent effect on the exchange of ions through the cell membrane in vitro and in vivo, it could be partially explain the impact of the insecticides and their mode of action.
\end{abstract}

Key words: Spodoptera littoralis, baculovirus, insecticides, cell lines

\section{INTRODUCTION}

Multiple resistance to pesticides has become widespread in at least 43 families belonging to 9 orders of insects, covering a wide range of the world's agricultural pests (Gehig, 1983). In addition, the environmental side effects concerning the toxicity of agricultural chemicals have resulted in increased restrictions on their registration and use. Yet it appears that, despite these developments, chemical pesticides will remain significant components in most pestmanagement programs. One strategy that may be able to retard the emergence of pesticide resistant insect populations and reduce the environmental load of chemical pesticides, is that which promotes the application of low levels of chemical pesticides with biological control spe- cific agents in particular nucleopolyhedrovirus (NPV) isolates. Various pesticide-NPV combinations have been evaluated for control of lepidopteran pests on cotton (Chapman and Ignoffo, 1972; Morris et al., 1974), vegetable crops (Hink, 1970; Jacques, 1973; Pfrimmer, 1979; Vail et al., 1980), and forest stands (McGarr and Ignoffo, 1966), generally with promising results. Until now there has been no direct evidence in vitro that NPV development is compatible with exposure to chemical pesticides, although there have been some studies in the literature that have evaluated the impact of chemical insecticides on insect cell cultures (Mitsuhashi et al., 1970; Stipanovic et al., 1990; Yoshida et al., 1979).

Thus, this study was undertaken to determine the effects of chemical insecticides on Spodop- 
tera littoralis $(S l)$ cell line division, growth and on Spodoptera littoralis MNPV development in the $S l$ cell line.

\section{MATERIALS AND METHODS}

Chemical insecticides. (Purity $>95 \%$ : Chloropyrifos 99\%; Cypermethrin 95.3\%; Fenitrothion 95.5\% ; Carbaryl 95\%) were obtained as active ingredients from the Central Laboratory of Pesticides, Ministry of Agriculture, Egypt. All standards were stored at $4^{\circ} \mathrm{C}$. Stock solutions were prepared in absolute ethanol $(>96 \%)$. The insecticides used in this study were Chloropyrifos and Fenitrothion from the organophosphate group, Cypermethrin from the pyrethroids and Carbaryl representing the carbamate group.

Cell line. The cell line used in this work, obtained from ovaries of Spodoptera littoralis was provided by Dr. G. Croizier (INRA, St. Christol, Les Alès, France). All the passages for cloning and experimental techniques were carried out in the Entomovirology laboratory in Cairo.

Cell line obtained from ovaries of Spodoptera littoralis pupae, was maintained as an attached cell line at $27^{\circ} \mathrm{C}$ in Grace's modified media (Lery and Fediere, 1990) with 15\% FBS (fetal bovine serum).

Effects and selection of insecticide concentration. The $S l$ cells were harvested from late logphase growth and seeded in P24 well plates at a concentration of $2 \times 10^{6}$ cells/plate. The insecticide dilutions were prepared in ethanol from a stock solution $\left(10^{-1}, 10^{-2} \ldots\right.$ to $\left.10^{-8}\right)$ and then added to the cell plates to a final solvent concentration of $0.5 \%$ ethanol (McCarthy et al., 1987; Takahashi et al., 1995). This procedure was to determine the insecticide concentrations which altered cell growth or had any cytopathological effect on $S l$ cells. The plates were incubated at $27^{\circ} \mathrm{C}$ in a constant humidity chamber. Cell number was determined after $4 \mathrm{~h}$ and then daily by Thoma hemocytometer at each pesticide concentration. The impact on the cells was determined by observation and photography under normal or phase contrast inverted microscope, at a magnification of 100 to 500 .

Virus-insecticide compatibility experiments. Pesticide concentrations which were lower than the concentrations that have a cytopathological effect on the cells or which altered cell growth were selected and retested in C35 mm petri dishes seeded with $5 \times 10^{5}$ cells/dish to confirm their effects on the $S l$ cells. To test the influence of chemicals on viral multiplication, 2 days post-treatment viral inoculation was carried out with $50 \mu \mathrm{l} 0.45 \mu \mathrm{m}$ filtered virions/dish, corresponding to a multiplicity of infection (MOI) of 0.5 with (Spodoptera littoralis nucleopolyhedrovirus, $S l$ NPV). The $S l$ NPV used in these experiments is an Egyptian isolate named BNS isolate, multiplied and cloned in vivo and in vitro in the laboratory.

Control plates were identically tested including the appropriate additions of solvent, except pesticides were omitted.

At $48 \mathrm{~h}$ to $72 \mathrm{~h}$ post-infection, the percentage of cells showing a cytopathological effect (polyhedra in the nucleus) was recorded. Ten days post infection, cells were counted and the percentage of infection was determined. Six concentrations were utilized in this study for chloropyrifos because the preliminary results indicated that this pesticide was a special case. Three replicates for every treatment were made.

TCID $_{50}$ (Plaque assay). $S l$ NPV inoculum was obtained from filtered $(0.45 \mu \mathrm{m})$ cell culture supernatant which resulted from the treated C $35 \mathrm{~mm}$ petri dishes described above. Viral titers from the cell culture medium were determined by the end-point dilution assay firstly described by Reed and Muench (1938) and adopted by Summers and Smith (1987). Two million cells were seeded in P24 well plates and allowed to attach. The cells were infected with virus at $10^{-1}$ to $10^{-9}$ concentrations and the plates were incubated at $27^{\circ} \mathrm{C}$. The plates were scored 7 days after infection, and the viral titer was expressed as the $\mathrm{TCID}_{50}$ per milliliter of cell culture medium, PFU values were also calculated for confirmation. This ratio was used to compare relative extra cellular viral (ECV) production of the cells to evaluate whether a reduction of $\mathrm{ECV}$ yield in pesticide treated cultures was due to a depressed yield per cell or a lower number of productive cells in the culture. 
Table 1. Effect of different pesticides on Spodoptera littoralis cell multiplication

\begin{tabular}{lll}
\hline \multicolumn{2}{c}{ Treatment } & \\
Insecticides & Conc. $(\mu \mathrm{g} / \mathrm{ml})$ & Number of cells $/ \mathrm{ml}$ \\
\hline Control & - & 0.29 \\
Chloropyrifos & 2.01 & 0.6 \\
& 1.005 & 0.51 \\
& 0.731 & 0.69 \\
& $10^{-1}$ & 0.72 \\
& $10^{-3}$ & 0.46 \\
Fenitrothion & $10^{-6}$ & 0.8 \\
& $10^{-4}$ & 0.22 \\
& $10^{-5}$ & 0.57 \\
Cypermethrin & $10^{-6}$ & 0.47 \\
& $10^{-3}$ & 0.4 \\
& $10^{-6}$ & 0.34 \\
& $10^{-7}$ & 0.43 \\
Carbaryl & $10^{-8}$ & 0.22 \\
& $10^{-5}$ & 0.42 \\
\hline
\end{tabular}

Number of cells $\left(\times 10^{6}\right)$ at 2 day post-treatment.

\section{RESULTS}

The effects of the utilized concentrations of each insecticide on the $S l$ cell line are shown in Table 1 and Fig. 1, and explain the different impacts of these insecticides on the division of $S l$ cells. The results in Tables 1 and 2 and Fig. 1 show unexpected findings for Chloropyrifos which enhanced cell multiplication. The number of $S l$ cells in each concentration treatment of this insecticide generally averaged 1.5 times (Table 2) and 2.15 times (Table 1) more than the number of untreated cells (control). The cell counts were taken $48 \mathrm{~h}$ post-treatment and gradually increased by the same proportion 4 days post-treatment; this over multiplication continued to the end of the experiment.
The most destructive insecticide was Cypermethrin, which caused the inhibition of $84 \%$ of $S l$ cells (Lysis) in the preliminary tests. The selected concentrations of the same pesticide also gave the lowest number of cells (Table 1) at the concentration of $10^{-8} \mu \mathrm{g} / \mathrm{ml}$.

With regard to the other tested insecticides, Table 1 shows that Carbaryl and Fenitrothion also enhanced cell multiplication, however, this was just for the first $48 \mathrm{~h}$. Thereafter, the effect was not seen throughout the end of the experiment. This fact is indicated by the number of cells for every concentration of each insecticide. The results in Tables 1, 2, and 3 show that the highest concentration of Chloropyrifos at $48 \mathrm{~h}$ post-treatment and the lowest concentration gave a number of cells two times and more than the untreated control cells. As for the Cypermethrin, the lowest concentration $\left(10^{-8} \mu \mathrm{g} / \mathrm{ml}\right)$ gave a number of cells that was less than the untreated control cells just like the highest concentration of Fenitrothion. For the two tested concentrations of Carbaryl, $10^{-5}$ and $10^{-6}$ $\mu \mathrm{g} / \mathrm{ml}$ and the lowest concentration of Fenitrothion, a number of cells of $1.49,1.65$ and 1.62 times more than the untreated control were respectively produced.

The results of viral replication in the presence of pesticides concentrations indicate that all pesticide treated $S l$ cultures, were not only permissive to infection by Spodoptera littoralis nucleopolyhedrovirus and showed typical viral cytopathological effects, but also enhanced the infection by the presence of pesticides compared with untreated cells (Table 3). Except for the highest concentration of Chloropyrifos $(2.01 \mu \mathrm{g} / \mathrm{ml})$, the percentage of viral infection $(40.7 \%)$ was less than the untreated control cells (48.1\%). Cypermethrin gave the lowest num-

Table 2. Effect of Chloropyrifos on $S l$ cell line multiplication

\begin{tabular}{ccccc}
\hline \multirow{2}{*}{$\begin{array}{c}\text { Chloropyrifos } \\
\text { conc. }(\mu \mathrm{g} / \mathrm{ml})\end{array}$} & 0 time & 2 days p.t. & 4 days p.t. & 7 days p.t. \\
\cline { 2 - 5 } & $2 \times 10^{5}$ & $5.8 \times 10^{5}$ & $3.84 \times 10^{6}$ & $4.05 \times 10^{6}$ \\
\hline Control untreat. & $2 \times 10^{5}$ & $1.2 \times 10^{6}$ & $3.5 \times 10^{6}$ & $4.35 \times 10^{6}$ \\
2.01 & $2 \times 10^{5}$ & $1.44 \times 10^{6}$ & $3.85 \times 10^{6}$ & $5.34 \times 10^{6}$ \\
$10^{-1}$ & $2 \times 10^{5}$ & $9.2 \times 10^{5}$ & $5.78 \times 10^{6}$ & $4.05 \times 10^{6}$ \\
$10^{-3}$ & $2 \times 10^{5}$ & $1.6 \times 10^{6}$ & $5.12 \times 10^{6}$ & $5.61 \times 10^{6}$ \\
$10^{-6}$ & & & & \\
\hline
\end{tabular}

p.t., post-treatment. 

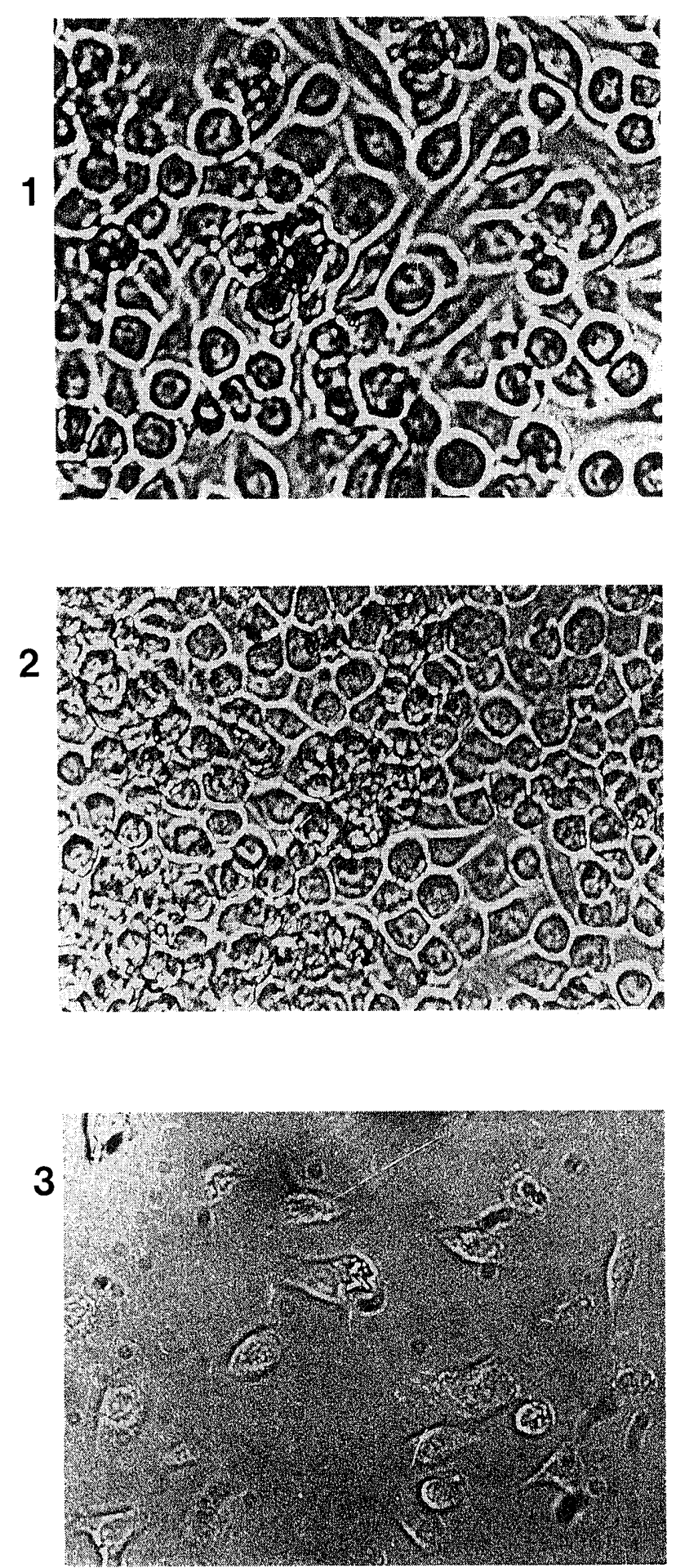

Fig. 1. Effect of pesticides on Spodoptera littoralis NPV development in $S l$ cells, 4 days post-infection. 1, untreated $S l$ cells multiplication; 2, Chloropyrifos treated $S l$ cells (over multiplication); 3, the inhibition effect of Cypermethrin on $S l$ cells multiplication.

ber of cells (inhibited cellular multiplication to $1.485 \times 10^{6}, 1.485 \times 10^{6}$ and $1.77 \times 10^{6}$ cells $/ \mathrm{ml}$ for the three tested concentrations $10^{-6}, 10^{-7}$ and $10^{-8} \mu \mathrm{g} / \mathrm{ml}$ respectively), and the highest percentage of viral infectivity (78\% in a total number of cells $1.77 \times 10^{6}$ cells $/ \mathrm{ml}$ at a concentration of $10^{-8} \mu \mathrm{g} / \mathrm{ml}$ ). The total number of cells $/ \mathrm{ml}$ in the untreated (neither insecticide nor virus) culture was $3.05 \times 10^{6} \mathrm{cells} / \mathrm{ml}$, the total number of virus (alone without chemicals as a 
Table 3. Effect of pesticides on Spodoptera littoralis NPV development in Sl cells

\begin{tabular}{|c|c|c|c|c|c|}
\hline \multicolumn{2}{|c|}{ Treatment } & \multirow{2}{*}{$\mathrm{TCID}_{50} / \mathrm{ml}$} & \multirow{2}{*}{$\mathrm{PFU} / \mathrm{ml}$} & \multirow{2}{*}{$\begin{array}{l}\% \text { of viral } \\
\text { infectivity }\end{array}$} & \multirow{2}{*}{$\begin{array}{c}\text { Total number } \\
\text { of cells } / \mathrm{ml}\end{array}$} \\
\hline Insecticides & Conc. $(\mu \mathrm{g} / \mathrm{ml})$ & & & & \\
\hline & untreated & - & - & - & 3.05 \\
\hline Control & virus alone & $5.11 \times 10^{8}$ & $3.5 \times 10^{9}$ & 48.1 & 2.025 \\
\hline \multirow[t]{6}{*}{ Chloropyrifos } & 2.01 & $9.29 \times 10^{10}$ & $6.41 \times 10^{11}$ & 40.7 & 2.175 \\
\hline & 1.005 & $2.00 \times 10^{10}$ & $1.38 \times 10^{11}$ & 60.1 & 3.12 \\
\hline & 0.731 & $9.29 \times 10^{12}$ & $6.41 \times 10^{13}$ & 59.4 & 2.955 \\
\hline & $10^{-1}$ & $6.86 \times 10^{11}$ & $4.73 \times 10^{12}$ & 64.6 & 2.67 \\
\hline & $10^{-3}$ & $4.62 \times 10^{7}$ & $2.8 \times 10^{8}$ & 57 & 2.025 \\
\hline & $10^{-6}$ & $7.51 \times 10^{11}$ & $5.18 \times 10^{12}$ & 54 & 2.805 \\
\hline \multirow[t]{3}{*}{ Fenitrothion } & $10^{-4}$ & $5.24 \times 10^{9}$ & $3.61 \times 10^{10}$ & 74.4 & 2.34 \\
\hline & $10^{-5}$ & $2.58 \times 10^{10}$ & $1.78 \times 10^{11}$ & 75.7 & 2.28 \\
\hline & $10^{-6}$ & $2.50 \times 10^{9}$ & $1.73 \times 10^{10}$ & 64.1 & 1.965 \\
\hline \multirow[t]{3}{*}{ Cypermethrin } & $10^{-6}$ & $6.53 \times 10^{8}$ & $4.5 \times 10^{9}$ & 70.7 & 1.485 \\
\hline & $10^{-7}$ & $4.00 \times 10^{8}$ & $2.76 \times 10^{9}$ & 70.7 & 1.485 \\
\hline & $10^{-8}$ & $6.48 \times 10^{5}$ & $4.47 \times 10^{6}$ & 78 & 1.77 \\
\hline \multirow[t]{2}{*}{ Carbaryl } & $10^{-5}$ & $1.42 \times 10^{12}$ & $9.76 \times 10^{12}$ & 54 & 2.415 \\
\hline & $10^{-6}$ & $1.13 \times 10^{9}$ & $7.82 \times 10^{9}$ & 75.1 & 3.075 \\
\hline
\end{tabular}

Number of cells $\left(\times 10^{6}\right)$ and percentage of infection were surveyed 10 days post-infection.

positive control) treated cells (virus alone without chemicals as a positive control) was $2.025 \times$ $10^{6}$ cells $/ \mathrm{ml}$ (Table 3 ).

The number of polyhedra (PIB) present in a cell averaged between 30 to 40 polyhedra/cell in the untreated control cells, whereas it averaged between 50 to $65 \mathrm{PIB} /$ infected cell, with all treated cells, even those treated by the Cypermethrin which inhibits the cell development (as previously described), to the lowest number of cells with the highest \% of infection.

A comparison of the $\mathrm{TCID}_{50}$ values (Table 3 ) revealed that, in the presence of both $S l$ NPV and sub lethal doses of the insecticides, Cypermethrin $\left(10^{-8} \mu \mathrm{g} / \mathrm{ml}\right)$ was the most toxic $\left(\mathrm{ID}_{50}\right.$ was $6.48 \times 10^{5} / \mathrm{ml}$ ), whereas the Chloropyrifos was the least toxic $\left(\operatorname{ID}_{50} 9.29 \times 10^{12} / \mathrm{ml}\right)$ for the concentration of $0.7308 \mu \mathrm{g} / \mathrm{ml}$.

The PFU values confirm the same results that the same concentration of Chloropyrifos was the least toxic $\left(6.41 \times 10^{13} / \mathrm{ml}\right)$ and Cypermethrin was the most toxic $\left(4.47 \times 10^{6} / \mathrm{ml}\right)$. For the other dilutions as well as the different insecticides, the PFU values ranged between $2.8 \times$ $10^{8}$ for Chloropyrifos $10^{-3} \mu \mathrm{g} / \mathrm{ml}$ and $9.76 \times$ $10^{12}$ for Carbaryl $\left(10^{-5} \mu \mathrm{g} / \mathrm{ml}\right)$.

A comparison with the results obtained using $S l$ NPV without chemicals (the PFU $3.5 \times 10^{9} /$ $\mathrm{ml}$ ) indicates an increase in the production of virus, and titer, and a synergistic effect of the chemicals.

\section{DISCUSSION}

The use of cell cultures for studies on insecticide effects instead of intact larvae provides several advantages, including reduced time cost for experimentation, on absence of obscuring enzyme systems typically present in larvae, and a relatively homogenous population of cells allowing strict measurement of pesticide effects.

This study also set out to determine whether alteration in cell numbers occurred as the result of an effect on cell division or as a direct lethal action on the cell. The results of previous studies on the effects of insecticides on the cells, tissues and organs of insects in vitro were far from conclusive, due in most instances to the small amount of growth obtained and the variability between the primary cultures (Mitsuhashi et al., 1970). The same authors (Mitsuhashi et al., 1970) upon examining 20 insecticides for their effects on the growth of insect cells in vitro, assumed that no differences in susceptibility were found for the cells derived from the moth Antheraea eucalipty and the mosquito Aedes aegypti. They also suggested that the functions of highly organized tissues in vivo are more readily interfered with than those 
of the individual cell types comprising them.

Although there have been no reports in the literature concerning the effects of pesticides on baculovirus development, the use of cell culture in vitro for such study has permitted the determination of a new and important factor which affects the division and virus-permeability of $S l$ cells in vitro.

There are a few somewhat dated studies concerning the effects of some pesticides on virus development in mammalian cells. Studies with vaccinia and poliovirus (Gabliks, 1967; Gabliks and Friedman, 1969) indicated that of the six pesticides tested (DDT, Chlordane, Dicolfol, Malathion, Dinocap, and Trichlorfon) all inhibited vaccinia virus replication in Chang liver cells, whereas Chlodane and Malathion inhibited poliovirus replication, and Dicolfol and Dinocap increased virus yield. Indeed, mammalian cell culture studies have shown that different pesticides affect cell metabolism in different and in some cases multiple ways.

It is well known that Carbaryl inhibits amino acid and uridine incorporation in an acid-precipitable form in Hela cells, whereas other pesticides (Chloropyrifos-Fenitrothion) do not interfere with either of these reactions but inhibit various esterases (Matsumura, 1980). Yoshida et al. (1979) indicated that the main origin of the toxicity of culture cells is due either to interference with respiration or to inhibition of macromolecular biosynthesis (RNA, DNA, and/or protein) irrespective of the origin of the cells. The organophosphates and carbamates are known to be cholinesterase inhibitors. No information is available on the presence of cholinesterase in insect cell lines. However, because cholinesterase is distributed in nervous tissues, whereas the moth ( $S$. littoralis) cells were derived from the ovarial sheath, it is possible that the cells may not contain this enzyme, and even if it is present in the cells they may not depend upon it for any vital function. If the hypothesis is correct the effects of carbamates and OP compounds should be considered as being due to a mechanism different from cholinesterase inhibition, particularly since they gave very different results in this study (Carbaryl reacted as an inhibitor and OP compounds enhanced the cells multiplication).
In addition Cypermethrin reacted as an effector of ion permeability (Matsumura, 1980). Thus, this may eventually explain why Cypermethrin was the most toxic insecticide in this study on $S l$ cell line. In addition, it could have altered the cell membrane permeability so that the transport of Cypermethrin into the cell became more efficient.

It could be concluded from this study that these pesticides did not affect ECV binding and uptake, as determined by subsequent PIB development. Therefore, at the cellular level, utilized pesticides used at low concentrations are quite compatible with $S$. littoralis NPV development in $S l$ cells. It could also be concluded that at the cellular level some pesticides at low concentrations are not only quite compatible with Spodoptera littoralis baculovirus development in $S$. littoralis cells, but may also enhance $S l$ polyhedral production. Thus, if other baculovirus-host cell systems show a similar tolerance to most pesticides as the $S$. littoralis cell and $S l$ NPV combination, the pest control strategy of combined applications of low levels of chemical pesticides and baculoviruses remains viable.

\section{REFERENCES}

Chapman, A. J. and C. M. Ignoffo (1972) Influence of rate and spray volume of a nucleo-polyhedrosis virus on control of Heliothis in cotton. J. Invertebr. Pathol. 20: 183-186.

Gabliks, J. (1967) Insecticidal compounds: Effects on replication of vaccinia and polio viruses in human Chang-strain liver cells. Arch. Environ. Health 14: 698-702.

Gabliks, J. and L. Friedman (1969) Effects of insecticides on mammalian cells and virus infections. Ann. NY Acad. Sci. 160: 245-271.

Gehig, R. R. (1983) Heliothis spp. baculoviruses: genetic characterization of geographical isolates, in vitro replication and molecular cloning. Ph.D. thesis, Penn. State Univ. 192 pp.

Grace, T.C.C. (1962) Establishment of four strains from insect tissue growth in vitro. Nature 195: 788-789.

Hink, W.F. (1970) Established insect cell line from the cabbage looper, Trichoplusia ni. Nature 226: 466-470.

Jacques, R.P. (1973) Tests on microbial and chemical insecticides for control of Trichoplusia ni Lepidoptera: Noctuidae) and Pieris repae (Lepidoptera-Pieridae) on cabbage. Can. Entomol. 105: 21-27.

Lery, X. and G. Fediere (1990) Effect of different amino acids and vitamins on Lepidopteran cell cultures. J. Invertebr. Pathol. 55: 47-51.

Matsumura, F. (1980) Modes of action of insecticides. In Toxicology of Insecticides. Plenum Press, New York and London, Chap. 4, pp. 105-163.

McCarthy, W. J., T. Hatfield and S. McMahon (1987) Effects 
of pesticides on division of two Lepidopteran cells and on Autographa californica MNPV development in TN368 cells. In Vitro Cell. Dev. Biol. 23(9): 621-626.

McGarr, R. L. and C. M. Ignoffo (1966) Control of Heliothis spp. with a nuclear polyhedrosis virus, EPN, and two newer insecticides. J. Econ. Entomol. 59: 1284-1285.

Mitsuhashi, J., T.D.C. Grace and D.F. Waterhouse (1970) Effects of insecticides on cultures of insect cells. Entomol. Exp. Appl. 13: 327-341.

Morris, O. N., J. A. Armstrong, G. W. Howse, J. C. Cunningham (1974) A 2-year study of virus chemical insecticide combination in the integrated control of the spruce budworm, Choristoneura fumiferana (Tortricidae: Lepidoptera). Can. Entomol. 106: 813-824.

Pfrimmer, T. R. (1979) Heliothis spp.: Control on cotton with pyrethroids, carbamates organophosphates, and biological insecticides. J. Econ. Entomol. 72: 593-598.

Reed, L. J. and H. Muench (1938) A simple method of estimating fifty percent endpoints. Am. J. Hyg. 27: 493-497.

Stipanovic, R. D., M. H. Elissalde, D. W. Altman and J. O. Norman (1990) Cell culture bioassay to evaluate allelochemical toxicity to Heliothis verescens (Lepidoptera: Noctuidae). $J$. Econ. Entomol. 83: 737-741.

Summers, M.D. and G.E. Smith (1987) A Manual of Methods for Baculovirus Vectors and Insect Cell Culture Procedures. Texas Agric. Exp. Station, Bulletin No. 1555.

Takahashi, M., Y. Kono, K. Matsushita and J. Mitsuhashi (1995) Production ethanol by cultured insect cells. In Vitro Cell Dev. Biol.-Anim. 31: 876-879.

Vail, P.V., R.E. Seay and J. DeBolt (1980) Microbial and chemical control of the cabbage looper on fall lettuce. $J$. Econ. Entomol. 73: 72-75.

Yoshida, M., M. Onaka, T. Fujita and M. Nakajima (1979) Inhibitory effects of pesticides on growth and respiration of cultured cells. Pesticide Biochem. Physiol. 10: 313-321. 